\title{
Smoking Behavior and Attitude towards Cigarette Warning Labels among Informal Workers in Surabaya City - East Java, Indonesia
}

\author{
Rita Kirana ${ }^{1}$, Vonny Kresna Dewi, Tut Barkinah, Isnaniah, Agus Rachmadi \\ 1Nursing Department, Poltekkes Kemmenkes, Banjarmasin - Indonesia \\ E-mail: ritakiranafkm@gmail.com
}

\begin{abstract}
In Indonesia, based on the results of the Riskesdas 2010 there are big province with higher active smoker, which are West Java, East Java and West Java. This study aims to determine the smoking behavior and attitude towards cigarette warning labels among informal workers (pedicab driver and motorcycle taxi driver) in Surabaya city. Data were obtained through the administration of questionnaire to eighty respondents in random parks of Surabaya City. The result revealed that textual cigarette was the most accessible cigarette warning label to informal workers (pedicab driver and motorcycle taxi driver). It further implied that cigarette packs, print media/newspapers and billboards were the main sources of awareness of cigarette warning labels. Pearson's correlation result indicated a positive and significant association between informal workers (pedicab driver and motorcycle taxi driver)' smoking behavior and their attitude toward cigarette warning labels $(\mathrm{r}=0.21, \mathrm{p}<0.01)$. The study therefore suggests that informal workers should be educated on the relevance of cigarette warning labels and how it can help them to live a healthy driving life. Te study also suggests that needed a comprehensive effort to reduce the number of smokers.
\end{abstract}

Keywords: Smoking, Informal Worker, Behavior, attitude, warning label

\section{Introduction}

Indonesia ranks fifth highest cigarette consuming countries, the WHO predicts that by 2020, the disease caused by smoking will result in the death of approximately 8.4 million people in the world and half of these deaths are from Asia. In Indonesia, based on the results of the Riskesdas 2010 there are big province with higher active smoker, which are West Java, East Java and West Java. Smoking is a risk factor for six of the eight leading causes of death worldwide (WHO, 2008). Smoking significantly contribute to chronic PTM, especially heart disease, stroke, cancer (lung, larynx, oral cavity, pharynx and esophagus), and chronic obstructive pulmonary diseases (COPD) (Ezzati, 2005). Report of the World Health Organization (WHO) on the Global Tobacco Epidemic in 2008 highlighted that approximately 5.4 million deaths annually associated with the use of tobacco / cigarettes. This means that every single minute of not less nine people died as a result of toxins in cigarettes or in every six seconds in the world will happen one case of death caused by smoking. This figure is more than the combined tuberculosis, HIV / AIDS and malaria (WHO, 2008). Despite the fact that the habit of smoking a major health problem in Indonesia and causes more than 200,000 deaths per year, Indonesia is the only country in the region that have not signed the WHO Framework Convention on Tobacco Control. (Barber et al., 2008). According to the latest report from WHO on the world tobacco consumption, smoking prevalence in Indonesia is one of the highest in the world, $46.8 \%$ of men and $3.1 \%$ of women age 10 years and over were classified as smokers (WHO, 2011).

The number of smokers reached 62.8 million, $40 \%$ of whom come from the down economy. The results of the research carried out by the Demographic Institute of the University of Indonesia's Economic Faculty indicated that cigarette consumption in Indonesia accounted for 46.16 per cent of the population, Indonesia's Antara news agency reported. Man and female active smokers in Indonesia in 2012 increased by 35 percent or about 61.4 million in 2013, the research data showed. It was revealed that deaths caused by smoking-related diseases in 2010 reached 190,260, or about 12.7 percent of all the death cases in the same year.

Scientific evidence confirms that smoking has created a poverty cycle among Indonesian smokers. Households with smokers spent $11.5 \%$ of their household income on cigarettes compared to only $11 \%$ spent on fish, meat, eggs, and milk (Barber et al., 2008). Poor urban family smokers spent $22 \%$ of their weekly income on cigarettes (samba et al., 2007). At the same time, nationally, the lowest-income families consume on average 12 cigarettes daily. In other words, they spend up to $40 \%$ of their income on cigarettes (WHO, 2012). 
Based on Riskesdas 2007, the most smokers are come from lower education and economy level. Social groups with low economy that deserves attention is the formal sector workers including motorcycle taxis and pedicab drivers. Motorcycle taxi driver and pedicap driver are informal worker sector that had low economy status level. Based on observation, as long as waiting of customer these motorcycle taxi driver and pedicap driver usually fill the time with smoke that cigarette consumption tends to be higher.

The study of 108 motorcycle taxi driver who performed in Jakarta, Bekasi and Depok in 2006 showed that $85 \%$ had a motorcycle taxi driver smoking habits (Setiadji, 2009). Related with that, according to Mahoney (2010) in his research that some drivers smoke carelessly not minding the environment they are; most drivers see smoking as a way of live and a habit that cannot be compromised. In order to battle against this dangerous habit, a variety of interventions against smoking and cigarette warning labels have been applied in different settings (e.g., schools, medical centers, religion settings) (Kosmidou et al., 2008). In Indonesia, the government has used different measures to fight cigarette use. One of such measures is the use of anti-smoking warning messages such as "smokers" are liable to die young".. The use of health warning messages has been proven to increase motivations to quit smoking and quit attempts. The inscribing of warning labels on cigarette packs can contribute to tobacco control efforts through the provision of information about health effects and tobacco ingredients. Hammond et al., (2006) opined that 'strong, informative warnings increase consumer education on the negative effects of smoking and may motivate smokers to quit'. Nevertheless, the use of anti-smoking campaigns to fight tobacco use can be successful only when students are ready to change their attitudes towards smoking in line with cigarette warning label. There for, the purpose of this study was to determine the smoking behavior and attitude towards cigarette warning labels among informal workers (pedicab driver and motorcycle taxi driver) in Surabaya city-East Java, Indonesia. .

\section{Materials and Methods}

\section{Research Design}

This study employed the descriptive cross sectional research design because it covered informal workers from different tribes and socioeconomic background. Through this, the opinions of their smoking behavior and attitude toward cigarette warning labels were ascertained through the use of a questionnaire and observation.

\section{Participants}

The population of the study comprised informal workers (pedicab driver and motorcycle taxi driver).. Data were obtained through purposive sampling procedure informant with the informants were selected based on the instructions key person with over 17 years old criteria of age.

\section{Types and Sources of Data}

The study principally made use of primary data. The primary data employed included data on the possible reasons for smoking; data on smoking behavior and frequency and data on the awareness and perception of smoking impact on informal workers (pedicab driver and motorcycle taxi driver). The set of primary data listed above were obtained through the administration of copies of structured questionnaire to Informal workers (pedicab driver and motorcycle taxi driver) across random parks within Surabaya city of Indonesia.

\section{Procedure of Data Collection}

The questionnaire was administered with the aid of field assistants. This was done after the purpose of the survey and instruction on how to fill the questionnaire was explained to the sampled smokers by the field assistants. The questionnaire contained questions in relation to the study objectives. The questionnaire was divided into three sections. Section A measured informal workers' socioeconomic characteristics; Section B contained a number of questions designed to measure awareness and smoking behavior of informal workers using a 4 - point Likert scale with responses ranging from Strongly Agree= SA (4); Agree = A (3); Disagree = D (2); and Strongly Disagree $=$ SD (1), while Section C contained questions designed to measure the perception of Smoking Impact On informal workers using a 4 - point Likert scale with responses ranging from Strongly Agree= SA (4); Agree = A (3); Disagree = D (2); and Strongly Disagree = SD (1).

\section{Method of Data Analysis}

Data obtained from the questionnaire were analyzed using tables, simple percentages, cross tabulations, charts, Pearson's Product Moment Correlation (PPMC). In order to effectively carryout inferential analysis, the items coded for descriptive analysis were transformed into dummy variables Statistical computation was done with the aid of SPSS 17.0 for Windows. 


\section{Results}

\section{Socio -Economic Characteristics of Respondents}

Information on the socioeconomic characteristics of respondents shows that $100 \%$ of the respondents were males. This is not surprising as commercial transportation in this part of the world is perceived as a man's job; as such women are hardly seen in the business. The job status of respondents implied that majority of them $(66.25 \%)$ were motorcycle taxi drivers, while $33.75 \%$ were pedicap drivers. The ages of respondents show that $18.75 \%$ were within the ages of $17-25$ years; $41.25 \%$ of the respondents fell within the ages of $26-35$ years, $32.5 \%$ were within the ages of $36-45$ years, while $7.5 \%$ were respondents above 46 years old. The marital status of respondents indicates that $38.75 \%$ were unmarried, $47.5 \%$ were married, while $13.75 \%$ were individuals with marital problems (divorce). The educational status of respondents reveals that $11.25 \%$ had no formal education, $23.75 \%$ had foundational education (primary education), $28.75 \%$ had postprimary education, and $36.25 \%$ had post-secondary education. Information on the age of smoking reveals that majority of the respondents started smoking between the ages of $15-20$ years.

\section{Frequency of Cigarette Smoking}

Information on the frequency of cigarette smoking is depicted in Table 4.1.

Table 4.1. Frequency of cigarette smoking

\begin{tabular}{|l|c|c|}
\hline Options & Frequency & Percent \\
\hline Daily & 38 & 47.5 \\
\hline Occasional & 22 & 27.5 \\
\hline $3-5$ times a week & 11 & 13.75 \\
\hline Once a week & 9 & 11.25 \\
\hline Total & 80 & 100 \\
\hline
\end{tabular}

The table indicates that $47.5 \%$ of the respondents smoked cigarette daily/everyday, which shows that this category of people are cigarette addicts who may not feel okay without substance use, $27.5 \%$ of the respondents occasionally smoked cigarette, probably to reduce stress, to be awake and to feel high or to be bold; $13.75 \%$ and $11.25 \%$ smoked cigarette $3-5$ times a week and once a week respectively. These groups of individuals are noncigarette addicts or devotees who smoke at will.

\section{Frequency and Sticks of Cigarette Smoked}

Table 4.2. Frequency and sticks of cigarette smoked

\begin{tabular}{|l|r|r|r|r|r|}
\hline Frequency & \multicolumn{6}{|c|}{ Number of cigarette smoked per day or occasion } \\
\hline of smoking & 1 & $2-5$ & $6-10$ & $>10$ & Total \\
\hline Daily & 1 & 21 & 16 & 0 & 38 \\
\hline Percent & 1.25 & 26.25 & 20 & 0 & 47.5 \\
\hline Occasional & 6 & 13 & 0 & 3 & 22 \\
\hline Percent & 7.5 & 16.25 & 0 & 3.75 & 27.5 \\
\hline $3-5$ times a week & 5 & 6 & 0 & 0 & 11 \\
\hline Percent & 6.25 & 7.5 & 0 & 0 & 13.75 \\
\hline Once a week & 1 & 5 & 0 & 4 & 9 \\
\hline Percent & 1.25 & 6.25 & 0 & 5 & 11.25 \\
\hline Total & 13 & 45 & 16 & 7 & 80 \\
\hline
\end{tabular}

Table 4.2 provides information on the frequency and sticks of cigarettes smoked at different times of the day. It has it that among respondents that smoked cigarette daily, 21 (26.25\%) smoked $2-5$ sticks of cigarettes, 16 $(20.0 \%)$ smoked 6 - 10 sticks, while no respondent smoked more than 10 sticks of cigarette per day. This implies 
that $2-10$ sticks of cigarettes are usually smoked by commercial driver daily. And among those that smoke occasionally, majority (16.25\%) smoked $2-5$ sticks, while $6(7.5 \%)$ smoked only a stick and none smoked above 5 sticks. For those who smoked once a week, 5 (6.25\%) smoked $2-5$ sticks, while $4(5.0 \%)$ smoked more than 10 sticks. The assessment reveals that $2-5$ sticks of cigarette are usually smoked by commercial drivers. This finding conforms to those of Siddiqui et al., (2001) when they reported an average of 2 sticks of cigarette consumption among smokers.

\section{Possible Reasons for Tobacco Use}

The reasons for tobacco use among informal workers (pedicab driver and motorcycle taxi driver) are shown in Table 4.3.

Table 4.3. Possible reasons for smoking

\begin{tabular}{|l|r|r|}
\hline Options & Frequency & \multicolumn{2}{|l|}{ Percent } \\
\hline To be awake & 10 & 12.5 \\
\hline Relief from stress & 21 & 26.25 \\
\hline For boldness & 6 & 7.5 \\
\hline For fun & 13 & 16.25 \\
\hline To reduce nervousness & 11 & 13.75 \\
\hline For socialization & 5 & 6.25 \\
\hline No reason & 14 & 17.5 \\
\hline Total & 80 & 100 \\
\hline
\end{tabular}

Table 4.3 indicates that relief from stress $(29.4 \%)$, for no obvious reason (24\%), for fun (17.5\%) and for boldness (in terms of courageous in driving) were the main reasons while informal workers (pedicab driver and motorcycle taxi driver) smoke cigarette. Earlier studies by Oshodi et al., (2010) affirmed this when they alleged that people smoke cigarettes to relieve stress, to stay awake or because they are influenced by their peers. Other reasons for tobacco use though of insignificant effects included to reduce nervousness, to be awake, to reduce tension and for socialization with co-smokers. The information however implies that informal workers (pedicab driver and motorcycle taxi driver) smoke cigarette daily and occasionally to relief stress, for fun and for reduce nervousness.

\section{Accessible means of cigarette warning labels}

Table 4.4: Means of accessing cigarette warning labels

\begin{tabular}{|l|l|l|}
\hline Options & Frequency & Percentage \\
\hline Graphics & 10 & 12.5 \\
\hline Textual & 51 & 63.75 \\
\hline Multi-media aids like video/television & 19 & 23.75 \\
\hline Total & 80 & 100 \\
\hline
\end{tabular}

Table 4.4 gives information on the accessibility of cigarette warning labels to informal workers (pedicab driver and motorcycle taxi driver) in Surabaya city. It shows that textual cigarette label (63.75\%) which is usually provided at the side of cigarette packs such as "tobacco smokers are liable to die young among others" was the most accessible cigarette warning label to informal workers (pedicab driver and motorcycle taxi driver); this was followed by multimedia devices like video placed beside the road, while the lest available graphics $(12.5 \%)$ which is often found in newspapers, billboards and tracks cigarette label was. This result agrees with that of PHC (2010) that health warning messages on tobacco products are a vital means of conveying information about the health risks of smoking. 


\section{Awareness of cigarette warning label}

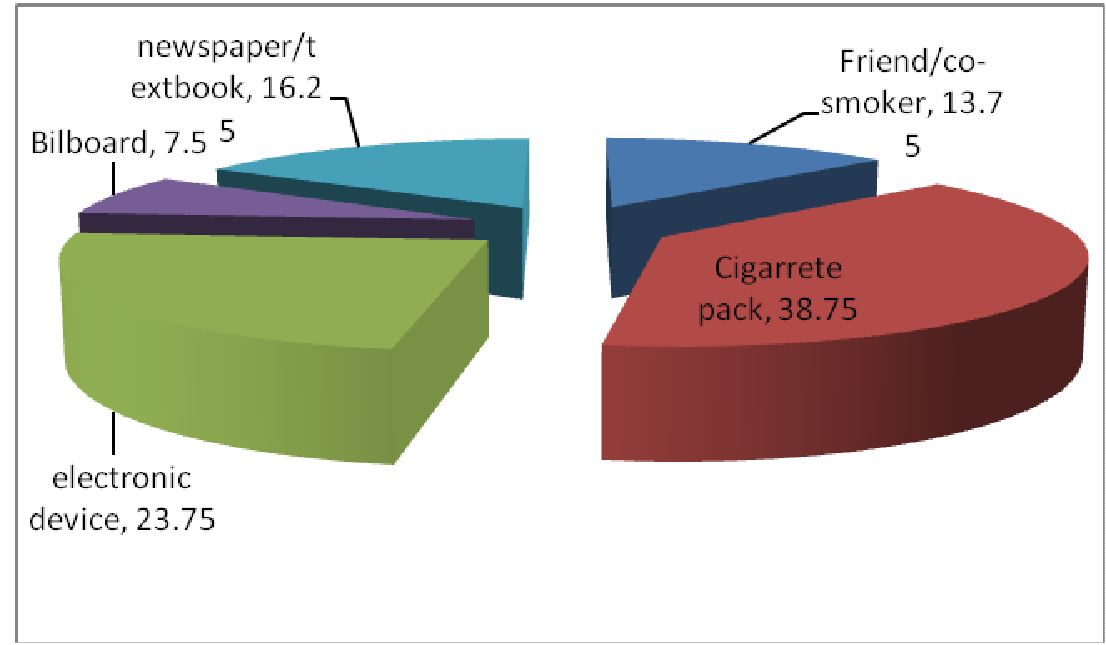

Fig. 4.1 Sources of cigarette warning label awareness

Fig 4.1 gives information on the various sources through which awareness of cigarette warning label is enhanced. All the respondents were of the opinion that they are aware of cigarette warning labels. The information showed that cigarette pack were the main sources of cigarette warning labels awareness available to smokers. Another potent source of awareness creation is through cigarette packs, though some of the smokers alleged that they seldom had time reading through the inscribed messages. They further asserted that the messages provided by the electronic media such as TV and radio are enough to influence their decision to quit smoking. Other sources of awareness creation included through advice from friends/relatives/co-smokers and newspaper/textbook. The truth is that cigarette warning labels are hardly posted on billboards; as such it is less used. These media carry varying messages on the health implications of cigarette smoking. According to Kin (2009) in his study, all Malaysian females were exposed to the national anti-smoking campaign that utilized all major media channels such as television, billboards, newspapers and radio, result obtained showed that television emerged as one of the major sources of anti-smoking messages in Thailand, the Philippines and Vietnam, but health warnings on cigarette packs is the other important channel.

\section{Attitude of undergraduate students towards cigarette warning labels}

The attitude of informal workers (pedicab driver and motorcycle taxi driver) towards cigarette warning labels is presented in Table 4.5 .

Table 4.5: Attitude of commercial drivers towards cigarette warning labels

\begin{tabular}{|l|r|r|r|r|}
\hline Variables & SA & A & D & SD \\
\hline Available cigarette warning labels are & 4 & 0 & 31 & 45 \\
poorly advertised & 5 & 0 & 38.75 & 56.25 \\
\hline Warning labels printed on cigarette packs are & 21 & 33 & 17 & 9 \\
more effective deterrent to smoking & 26.25 & 41.25 & 21.25 & 11.25 \\
\hline $\begin{array}{l}\text { Cigarette warning labels pass on vital information } \\
\text { on the consequences of smoking }\end{array}$ & 43 & 20 & 12 & 5 \\
\hline Cigarette warning labels do not & 53.75 & 25 & 15 & 6.25 \\
influence smoking & 14 & 3 & 41 & 22 \\
\cline { 2 - 5 } & 17.5 & 3.75 & 51.25 & 27.5 \\
\hline
\end{tabular}

The Table showed that $95 \%$ of the respondents were of the opinion that cigarette warning label is not poorly advertised. This implies that anti-smoking messages are properly disseminated and smokers are aware of the health consequences. It also indicated that $78.75 \%$ of the respondents had the opinion that cigarette warning labels convey vital information about the health risks of smoking. The frequent supply of anti smoking messages 
positively influences smokers' decisions to quit or reduce the frequency of cigarette consumption. This agrees with Margaret, (2010) that in Canada, cigarette labels have been required to display a message from the United States Surgeon General warning of the punitive effects of cigarettes on health and mortality. It also agrees with the findings of PHC, (2010) that health warning messages on tobacco products (packs) are a vital means of conveying information about the health risks of smoking. Furthermore, $78.75 \%$ of the respondents refuted the assertion that cigarette warning labels do not influence smoking behaviour. This showed that the intention of informal workers to reduce their smoking frequency as well as the number of sticks smoked daily may be based on the health information they received from reading anti-smoking messages. This is consistent with the assertion of Hammond et al., (2004) that strong and informative warnings increase consumer education on the negative effects of smoking and may motivate smokers to quit.

\section{Relations between smoking behavior and cigarette warning labels}

Pearson Product Moment correlation was used to determine the nature of association between cigarette smoking behavior and attitude toward cigarette warning labels.

Table 4.6. Pearson's correlations of the relationship between cigarette smoking behavior and attitude towards cigarette warning labels

\begin{tabular}{|l|lr|r|}
\hline Test statistics & $\begin{array}{l}\text { Cigarette } \\
\text { behavior }\end{array}$ & smoking & $\begin{array}{l}\text { Attitude towards cigarette } \\
\text { warning labels }\end{array}$ \\
\hline Pearson Correlation & & 1.00 & \\
Sig. (2-tailed) & & & 0.217 \\
N & & & 0.005 \\
\hline
\end{tabular}

The r-value result in Table 4.6 indicated a positive and significant relationship between cigarette smoking behavior and their attitude toward cigarette warning labels $(r=0.42, p<0.01)$. This result indicated that informal workers' cigarette smoking behaviour is directly related to their attitude towards cigarette warning labels. This may logically imply that as informal workers develop positive attitude, the tendency of smoking reduces but if smokers have negative attitude towards cigarette warning labels (disregard information provided), it may result in risky smoking behavior. For instance, smokers that believe cigarette has no effect tend to consume more sticks of cigarette compared to those that have positive attitude towards cigarette labels..

\section{Discussion}

The study reports that informal workers (pedicab driver and motorcycle taxi driver) smoke cigarette daily/everyday, and occasionally. For those that smoke daily, it shows that they are cigarette addicts who feel unease without substance use, as it is consumed to relieve stress, to be awake and to be bold. Fiore et al., (2000) report that most smokers offer similar reasons for their smoking. Typically, they report that smoking is an addictive habit that they enjoy and that relieves stress. Light smokers tend to smoke more for social reasons while heavy smokers are more likely to report that they smoke because of the addictive nature of tobacco. The reasons for tobacco use among informal workers (pedicab driver and motorcycle taxi driver) are to be relief from stress, for no obvious reason, for fun and for boldness (in terms of courageous in driving). The study furthermore shows that several important factors such as age, education, age or status may influence informal workers (pedicab driver and motorcycle taxi driver)' decisions to consume cigarettes.

The analysis reveals that informal workers (pedicab driver and motorcycle taxi driver) in Surabaya city are aware of cigarette smoking labels, but their attitudes towards the messages the warning label convey vary. The result reveals that textual cigarette label which is usually provided at the side of cigarette packs as well as on billboards such as "tobacco smokers are liable to die young among others" is the most accessible cigarette warning label to informal workers. This finding agrees with that of PHC (2010) that health warning messages on tobacco products are a vital means of conveying information about the health risks of smoking. The study observes that cigarette packs, electronic devices and newspapers/textbook are the main sources of cigarette warning labels awareness to informal workers (pedicab driver and motorcycle taxi driver); other sources of awareness creation include through the advice from friends/co-smokers and billboard. These media carry varying messages on the health implications of cigarette smoking.

The result shows that cigarette warning labels convey vital information about the health risks of smoking. This result indeed is obvious as the constant supply of textual messages or positively influences smokers' decisions to quit or reduce the frequency of cigarette consumption. This agrees with Margaret (2010) that in Canada, cigarette 
labels have been required to display a message from the United States Surgeon General warning of the punitive effects of cigarettes on health and mortality. In all, $62.8 \%$ of the respondents strongly asserted that cigarette warning labels are vital means of conveying information about the risks inherent in cigarette smoking. The study reveals that informal workers (pedicab driver and motorcycle taxi driver)' cigarette smoking behaviour is directly related to their attitude towards cigarette warning labels. This implies is that if smokers have negative attitude towards cigarette warning labels (disregard information provided), it may result in risky smoking behavior.

For instance, smokers that believe cigarette has no effect tend to consume more sticks of cigarette compared to one that has positive attitude towards cigarette labels. The research also shows apparently that there is significant difference in the attitude of commercial drivers towards cigarette warning labels. This implies that informal workers (pedicab driver and motorcycle taxi driver)' attitude towards cigarette warning labels varies, as some smokers' behaviour and decision to quit is influenced by the nature of warning label, while others irrespective of the labels and messages smoke uncontrollably.

\section{Conclusion}

The study shows that informal workers (pedicab driver and motorcycle taxi driver) in Surabaya city are aware of cigarette smoking labels, but they have different attitudes and perceptions toward cigarette messages. Cigarette packs, newspapers/textbook and billboards are the main sources of cigarette warning labels awareness to informal workers (pedicab driver and motorcycle taxi driver). The study posits that constant supply of textual messages positively influences smokers' decisions to quit or reduce the frequency of cigarette consumption. This result can be attributed to factors such as public awareness on the negative consequences of smoking, antismoking campaigns and formal participation against cigarette smoking. The study therefore suggests that informal workers (pedicab driver and motorcycle taxi driver) should be educated on the relevance of cigarette warning labels and how it can help them to live a healthy driving life.

\section{References}

Balitbangkes Kemenkes RI. 2008. Laporan Nasional Riset Kesehatan Dasar 2007. Kementerian Kesehatan , Republik Indonesia: Jakarta.

Balitbangkes Kemenkes RI. 2011. Laporan Nasional Riset Kesehatan Dasar 2010. Kementerian Kesehatan , Republik Indonesia: Jakarta.

Barber S, Ahsan A, Adioetomo SM, Setyonaluri D. 2008. Tobacco economics in Indonesia. Paris: International Union against Tuber-culosis and Lung Disease.

Ezzati M, et.al. 2005. Role of smoking in global and regional cancer epidemiology: current patterns and data needs. Int J Cancer 2005; 116: 963-71. [available at: http://onlinelibrary.wiley.com/doi/10.1002/ijc.21100/full

Fiore, M.C., Bailey, W.C. and Cohen, S. J. (2000). Treating Tobacco Use and Dependence. Clinical Practice Guideline. Rockville, MD: U.S. Department of Health and Human Services. http://www.surgeongeneral/tobacco/default.htm.

Hammond, D., McDonald, P.W., Fong, G.T., Brown, K.S. and Cameron, R. (2004). The Impact of Cigarette Warning Labels and Smoke-Free Bylaws on Smoking Cessation: Evidence from Former Smokers. Can J Public Health, 95(3):201 - 205.

Institute of Medicine. 2007. Ending the Tobacco Problem: A Blue print for the Nation, The National Academies Press, Washington, DC, USA.

Kosmidou, E., Theodorakis, Y. and Chroni, S. (2008). Smoking Attitudes among Adolescents: Effect of Messages Varying on Argument Quality and Source's Expertise. Journal of Social, Behavioral, and Health Sciences, 2: $83-95$.

Mahoney, J. (2010). Strategic Communication and Anti-Smoking Campaigns. Public Communication Review, 1 (2): $33-48$.

Margaret, A. (2010). The Cigarette Package as Tobacco Company Marketing Tool. Commissioner of Food and Drugs, Food and Drug Administration, 5630 Fishers Lane, Room 1061 - Rockville, MD 20852.

Oshodi1, O.Y., Aina, O.F. and Onajole, A.T. (2010). Substance Use among Secondary School Students in an 
Urban Setting in Nigeria: Prevalence and Associated Factors. African J. Psychiatry, 13: 52 - 57.

Peto, R. and Lopez, A.D. (2000) The Future Worldwide Health Effects of Current Smoking Patterns. In: Koop CE, Pearson CE, Shwarz M. R (eds) Global Health in the 21st Century. New York.

PHC. (2010). Evaluating the Impact of Picture Health Warnings on Cigarette Packets. PHRC (Public Health Research Consortium) Short Report 12, 1 - 4.

Setiadji, B. 2009. Pengaruh promosi kesehatan terhadap perilaku merokok pada pekerja informal : studi kasus tukang ojek. Disertasi Fakultas kesehatan masyarakat, Universitas Indonesia, Depok.

Strahan, E.J., White, K., Fong, G.T., Fabrigar, L.R., Zanna, M.P. and Cameron, R. (2002). Enhancing the Effectiveness of Tobacco Package Warning Labels: A Social Psychological Perspective. Tobacco Control, 11:183-190.

World Health Organization. 2008. WHO report on the global tobacco epidemic. The MPOWER package. Geneva: World Health Organization; 2008, 14-15.

World Health Organization. Global Adult Tobacco Survey (GATS): Indonesia report 2011. Jakarta: WHO Regional Office for South East Asia 2012. 
The IISTE is a pioneer in the Open-Access hosting service and academic event management. The aim of the firm is Accelerating Global Knowledge Sharing.

More information about the firm can be found on the homepage:

http://www.iiste.org

\section{CALL FOR JOURNAL PAPERS}

There are more than 30 peer-reviewed academic journals hosted under the hosting platform.

Prospective authors of journals can find the submission instruction on the following page: http://www.iiste.org/journals/ All the journals articles are available online to the readers all over the world without financial, legal, or technical barriers other than those inseparable from gaining access to the internet itself. Paper version of the journals is also available upon request of readers and authors.

\section{MORE RESOURCES}

Book publication information: http://www.iiste.org/book/

\section{IISTE Knowledge Sharing Partners}

EBSCO, Index Copernicus, Ulrich's Periodicals Directory, JournalTOCS, PKP Open Archives Harvester, Bielefeld Academic Search Engine, Elektronische Zeitschriftenbibliothek EZB, Open J-Gate, OCLC WorldCat, Universe Digtial Library, NewJour, Google Scholar

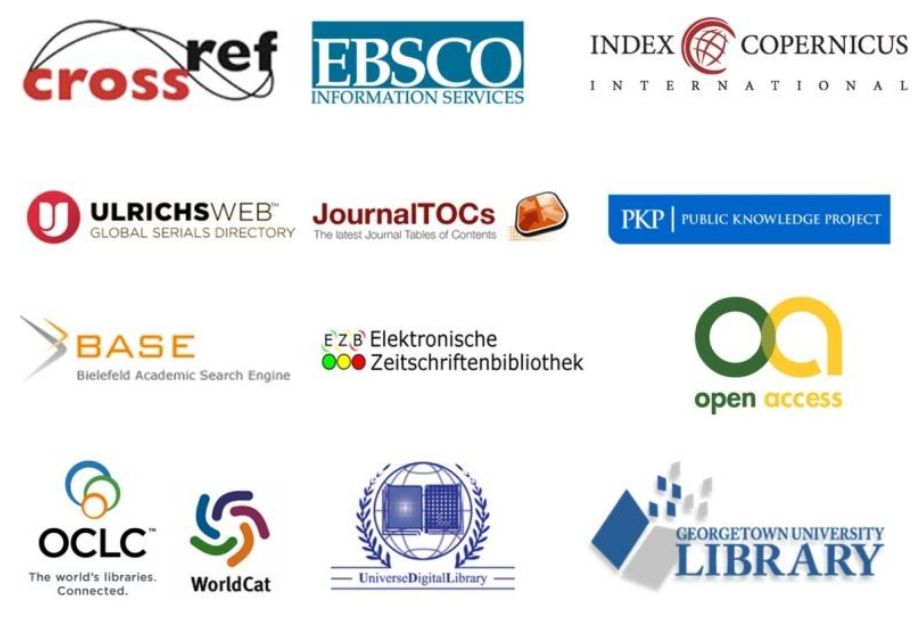

